\title{
Invisible and Ignored: The Archaeology of Nineteenth-Century Subalterns in Sweden
}

\section{Martin Hansson $^{1}$ (D) Pia Nilsson ${ }^{2} \cdot$ Eva Svensson $^{3}$}

Published online: 28 February 2019

(C) The Author(s) 2019

\begin{abstract}
This paper aims to discuss subalterns in different social environments in Sweden. The potential of archaeological studies of landless subalterns in rural and urban areas are shown though a number of case studies. It is argued that archaeology can show the multivocality of the lives of the subalterns, in the same way as it shows how the subalterns organized their daily life. This is done through the use of the concepts of matterscape, powerscape, and mindscape. The subalterns used the physical landscape (matterscape) according to prevailing norms and power structures (powerscape), thus creating a perceptive understanding of their daily landscape (mindscape).
\end{abstract}

Keywords Subalterns $\cdot$ Multivocality $\cdot$ Sweden $\cdot$ Matterscape $\cdot$ Mindscape

\section{Introduction}

This paper aims to discuss subalterns in Sweden, focusing on different social environments: subalterns among peasants, in urban areas, and in patriarchal milieus (manors and industries). The background is the introduction of major changes in the Heritage Conservation Act in Sweden in 2014. A radical novelty is that remains of human activity and buildings erected before $1850 \mathrm{CE}$ now are legally protected sites. With this

Martin Hansson

martin.hansson@ark.lu.se

Pia Nilsson

pia.nilsson@arkeologerna.com

Eva Svensson

eva.svensson@kau.se

1 Department of Archaeology and Ancient History, Lund University, Box 192, 22100 Lund, Sweden

2 The Archaeologists, The National Historical Museum, Roxengatan 7, 58273 Linköping, Sweden

3 Department of Environmental and Life Sciences, Karlstad University, 65188 Karlstad, Sweden 
change, a large number of hitherto unresearched or under-researched remains will be included in heritage management, conservation, and contract archaeology. Thus, the new legal situation opens new possibilities for historical archaeology, but also poses challenges. In this article we will address one field that has come into focus due to the changed law, namely the field of landless subalterns in rural and urban areas. Archaeologists in Sweden have traditionally ignored this large group of people, thus making them invisible in the archaeological record. In this paper we argue that doing archaeology connected to the heritage of the subalterns produces new and independent knowledge in relation to traditional historical research. Specific use will be made of Swedish case studies where subalterns in different social contexts have been studied by triangulating material culture, written documents, maps, and folklore, in order to see if and how attitudes toward subalterns differed between urban areas and the countryside.

Research and documentation of the living conditions of subalterns and poor people in Sweden have occurred since the end of the nineteenth century, but in scholarly disciplines other than archaeology. This research has concerned different aspects of the history of subalterns, but have mainly focused on rural conditions, especially on crofters. The number of archaeological excavations that have concerned crofters and other sites connected to subalterns is so far rather small, especially if related to the large number of excavations that are conducted every year within Swedish contract archaeology (according to the Heritage Conservation act).

The archaeology of subalterns in Sweden, in the sense of crofters, emerged in the 1990s, but has for many years been connected to a few scholars (Rosén 1999, 2001; Svensson 2001; Welinder 1992a, b). In connection with the changes of the Heritage Conservation Act, material remains dating before 1850 are now considered ancient monuments in the same way as Stone Age settlements, Iron Age burials, medieval castles, and other "traditional" monuments. Many of these "new" sites are connected to the life of the subalterns, sites that previously have been disregarded. Even though many excavations of post-medieval remains are starting to emerge, research and analytical work must be developed further (cf. Høst-Madsen 2016; Svensson et al. 2018). The new legal situation in Sweden poses a challenge to develop agendas for making the remains of the subalterns more mainstream.

\section{Theory and Method}

The concept of subaltern is based on the ideas of the Italian Marxist Antonio Gramsci. According to Gramsci, subalterns (workers, landless people, etc.) were a heterogeneous group of people, united by the fact that they all were subordinated to the dominant groups in society (Bellini et al. 2010: Castree et al. 2013). In the 1980s the field of Subaltern Studies was established within South Asian studies, with the objective of trying to understand history from the perspective of the oppressed in society, often indigenous groups. Within this field, "subaltern" refers to a person of inferior rank by virtue of class, race, or gender (Chakrabarty 2000).

The concept of subalterns has also been used within historical archaeology. Historical archaeology has often tried to legitimize its position by pointing to the ability for archaeology to highlight the living conditions of people that are poorly represented in the historical written sources. This has led to a number of studies of subaltern groups, 
for example of African American slave settlements, or industrial workers in North America (McGuire 2006; Mrozowski 2000; Orser 1996:160-173; Orser and Fagan 1995:37, 57-58). The focus on subalterns has been an important part of the archaeological study of the emergence of capitalism.

In this article, we use the term subaltern as Gramsci intended, as a collective term for several different groups of subordinate people in nineteenthcentury Swedish society. In the countryside, it concerns people who did not own or control any land of their own. In the towns and at the industries it was the subordinate workforce, often with low wages and living in houses owned by the employer. Even though there were differences in living conditions within these groups of subalterns, they were united by their vulnerable, inferior rank in society and exposed living conditions. The term subalterns is more appropriate to use than other general term like "poor." It also functions better than using more specific terminology such as "crofters," "workers," and the like.

When working with nineteenth-century remains, the complex relation between written sources and material remains is the ever-present challenge to historical archaeology (cf. Andrén 1998; Little 2007; Mooreland 2001). There is constant pressure to show the independent value of doing archaeology in periods with an abundance of written sources. Material culture, however, must be the starting point for archaeology studying the heritage of subalterns (cf. Bodin et al. 2005; McGuire 2006; Mrozowski 2000; Orser 1996:159-183; Rosén 1999, 2001, 2007). In Sweden, these studies have included comparisons between material culture, especially from crofts, and what can be read in the archives. For example, it has become evident that the material culture that is listed in probate inventories is seldom found in archaeological excavations. What was listed in the inventories were artifacts of high value that continued to be in use. Others were of material that due to taphonomic processes is hardly ever preserved. On the other hand, many artifacts and groups of artifacts that actually are found in excavations are not mentioned in these inventories at all (cf. Rosén 2001). This is not the place to dwell on why this is so, just to underline that the results of archaeological excavations of late remains has the potential to produce new and independent knowledge. What has often become evident is that archaeological studies of subaltern milieus, especially in the countryside, in several cases have shown a much more multivocal history compared to the one presented in the written documents (cf. Knarrström 2008b).

An important aspect to notice is that while written documents about subalterns have been produced by people with power in the local society (e.g., the parish priest and other officials), the material culture found on sites connected to subalterns was directly produced and used by the people themselves (cf. Orser and Fagan 1995: 15-16, 38). One could thereby argue that material culture has a more direct connection to subalterns, compared to written sources and maps, which makes an analysis of the former both meaningful and important.

While traditional scholarly research about subalterns based on written documents often ends up compiling data for statistical comparison, thus creating some form of master narrative, comparing the living conditions of subalterns both synchronically and diachronically over large areas, archaeology is, as far as fieldwork is concerned, always local and connected to a place. It is true that archaeology has often been accused of being local, just highlighting a specific site, but this can also be seen as an advantage. 
First of all it helps to highlight the multivocality of history, showing that the master narratives often can be challenged, since archaeology for example finds traces of things unknown in the written sources (Apel and Welinder 2007; Orser and Fagan 1995:3839). Secondly, archaeology gives a historical situation a spatial context that traditional studies focused on written documents very seldom can. By doing archaeology we can analyze the space and landscape of the subalterns in detail.

Ordinary artifacts found in an archaeological excavation are the result of everyday life, objects dropped, being broken and thrown away. As such, they to a large extent represent the routinized behavior of everyday life. By applying contextual documentation methods it is possible to analyze spatial distribution of artifact patterns, in order to reveal the underlying, perhaps subconscious ideas behind this routinized behavior (cf. Knarrström 2008a:60; Orser and Fagan 1995:42). For example, the distribution of garbage reveals attitudes of subalterns toward concepts like cleanliness. A result of a study like this can be contrasted against the common view of subalterns as being poor, filthy, and living in unclean conditions (cf. Larsmo 2017; Rathje and Mullen 1992).

To understand the lives of subalterns, their material culture has to be seen in a spatial and social contexts. A landscape can be produced in many ways, by clearing arable fields, building roads, erecting borders, or constructing buildings, but the landscape is also created by the way in which people use it in their daily practice. People's daily practice gives the landscape its meaning and the daily practice is a reflection of the social order on many levels (Dodgshon 1987, 1998; Lefebvre 1991). To study the living conditions of subalterns, the conceptual model of matterscapes, mindscapes, and powerscapes can be used as an overreaching analytical framework. It (the framework) offers an explanatory model that links the physical world, the natural conditions constituting the material reality (matterscape), and the social and cultural conditions, for example implicit and explicit rules that regulate the behavior of a specific group (powerscape), to the inner subjective experiences of individuals of a specific landscape (mindscape). While matterscape consists of the material reality of the world, powerscape is the landscape produced by norms, objectives, and power structures, and mindscape is the personally experienced and perceived landscape (Jacobs 2006:8-9). This model can explain how subalterns used, understood, and perceived the physical world in relation to other groups in society, merging physical, social, and personal realities.

For example, the asymmetrical rights and possibilities of the subalterns in relation to material and environmental assets, and their vulnerability to risk exposure, affected their actions in the landscape. For instance, results from earlier studies (Nilsson 2010) show that numerous rural settlements with negligible acreage found strategies to survive through multifunctional economic activities, including iron and tar production and different types of handicrafts. This multivocality can be viewed as a result of a combination of matterscape, powerscape, and mindscape.

\section{Subalterns in the Countryside}

Crofts, in the sense of small agrarian units in a dependency position vis-à-vis the landowner, were already established during the Middle Ages in Scandinavia. A major transformation started in the eighteenth century with demographic growth and scarcity 
of land for establishing new smallholdings. Crofters did not pay any tax, but farmed another landowner's land and paid dues, either in cash, in kind, or by doing day labor. Most often, the dues were paid as stated in a contract between the crofter and the landowner. As long as the crofter fulfilled the obligations, the family could stay on the croft (Gadd 2000:85-86, 88). It should be emphasized that the term "crofters" in this article is used for a number of different categories of people entitled in various ways to live on other people's land (Sw. torpare, backstugusittare) (Fig. 1).

The number of crofters and crofts increased rapidly until the middle of the nineteenth century. From the mid-1800s on, other possibilities opened up, such as work in the industries in the towns and emigration. At the same time, an increasingly effective and ultimately mechanized agriculture made many crofters redundant. In Sweden, the great land division, Laga Skifte, in the second quarter of the nineteenth century left many of the crofters who lived by the villages and infields as homeless proletarians. The crofters on outlying lands were less vulnerable to proletarianization because they pursued more flexible economies than those near villages. In Sweden, the crofting institution was abolished in 1943 (Bäck 1992; Elgeskog 1945).

Other landless groups in the countryside were people living on the larger farms or even crofts, since they were unable for various reasons to support themselves ( $\mathrm{Sw}$. Inhysehjon). Some of these persons also worked as servants or as farm workers. Many in this group had previously been crofters, but due to financial problems, old age, or disease had been forced to leave the croft. This group of people functioned as a workforce reserve. Smaller crofts (backstugor) had very small arable fields built on common land. The user of a backstuga often supported himself on handicraft and day labor. Crofts (torp) had larger arable fields, but the line between the two types was often crossed, and written records frequently show that a settlement can switch from being seen as a torp or a backstuga (Gadd 2000:85-91). The line between a croft and a small farm was often also blurred.

A specific type of crofters were soldiers. Giving soldiers a croft where they could support themselves in peacetime became part of the military organization from the 1680 s onward. Each county had to keep a regiment of 1200 soldiers. The costs for maintaining the army were divided among the farmers in the county and the result was

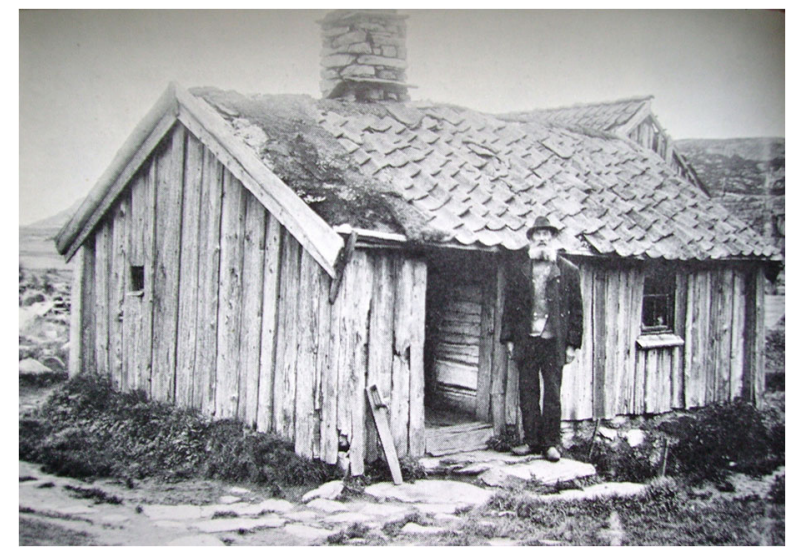

Fig. 1 Croft in Bohuslän, West Sweden, early twentieth century. Unknown photographer. (Nordiska museet/ Reports. Wikimedia Commons) 
a large number of soldiers' crofts. Many soldiers also survived on handicraft and as day laborers (Gadd 2000:91).

For the whole of Sweden, the number of crofters in 1750 was about $15 \%$ of the number of peasants. Regional variations were large, however. In regions with many manors, there were many crofts. Until 1800 the number of crofters increased by $130 \%$, from 28,000 to 65,000 . The increase continued, and culminated ca. 1860 with about 100,000 crofters in the whole of Sweden (Gadd 2000:88-89, 223).

The large increase in the group of subalterns in the period 1750-1850 is explained by the general public growth in the nineteenth century, which was mainly due to a decreasing death rate. When the population grew in number and the farms could not be divided any further, the group of people that, so to speak, was "left over" became landless subalterns (Gadd 2000:228-230).

Some crofters held their croft with a "pawn contract" (förpantningskontrakt), meaning that the crofter lent money to the landowner, often a farmer, for the right to use the land. This gave the crofter greater security and made it much more difficult for the landowner to evict the crofter. An eviction meant that all money, plus interest, had to be repaid, as well as a sum for all the farming that had been done. In practice, this was impossible for the landowner and meant that a crofter who had this type of contract got tenure to his land. In order to obtain such a contract, the crofter first needed to gather a large sum of capital (Elgeskog 1945:226, 241-245, 249-252). This meant that a croft could belong to the same family for generations, but the normal conditions were that the crofter with family often moved between different crofts (Gadd 2000:223).

The question of tenure is interesting from an archaeological perspective. Is it possible to see differences in the material culture between crofts held with different types of tenure? Is it possible to discern that a crofter with a "pawn contract," who in practice had full possession of his land, invested more in buildings and in clearings, since he knew that his children most certainly would benefit for this, in comparison to a crofter who had a much shorter contract?

\section{The Archaeology of Crofters in the Countryside: The Example of "Rosts täppa"}

The site called Rosts täppa ("Rost's patch") was partly excavated in 2003 in connection with the building of a new motorway in northeastern Scania. Even though the whole crofter's plot was not subject to excavation, the mapping of visible remains and a landscape analysis show the potential of archaeological investigations of this type of objects (the following presentation relies on the work of Annika Knarrström, see Knarrström 2008b, 2009). The building remains on the site were dated to the eighteenth and nineteenth centuries, and paleobotanical analysis showed that this was a recolonization of a deserted medieval farmstead.

The site was found in a location that often is connected to crofter's lodgings, in a remote position in the landscape, on a southern slope toward wetland in a moraine terrain, where the conditions for agriculture were far from optimal. The ruins of a tworoom building with a cellar were visible above ground, together with some pits and production facilities for charcoal and tar. Arable fields with some clearance cairns and lined with stone walls could be seen as well as pathways also lined with stone walls. An 
area to the south of the main building showed traces of having been cleared of stones, and here artifacts and layers of charcoal showed that this probably was the position of an outbuilding. The entrance to the croft was from the north, meaning that visitors approached the place from behind, since the main building had its entrance on the southern side. The whole place was situated just on the northern side of a large area of wetland, which probably was used for harvesting grass. A well and two storage pits could also be found north and northeast of the main building. Stone walls of different sorts as well as stone-lined terraces of $600 \mathrm{~m}$ had been built (Fig. 2).

Yet another, even smaller site was found about $270 \mathrm{~m}$ to the east. Here a small building could be documented in an area with clearance cairns, showing that smallscale farming had taken place. The artifacts found, for example ceramics, dated the place to the same period as the larger site. Interestingly, it could be seen that the ceramics had been broken and holes in the sherds had been made, evidence of attempts to mend the vessels. Considering the low value of simple ceramics in the nineteenth century, this must be seen as a clear example of the poverty of the inhabitants (Fig. 3). Also at this site, pits for charcoal production were found. This site was however not known in any written records and not visible on any map.

The two sites were located on the outfields of the small hamlet of Värsjö, situated about $2 \mathrm{~km}$ to the east. While Värsjö was a farm/hamlet of probable medieval origin, first mentioned 1579, the croft is not mentioned until the early nineteenth century. The place is marked as "Rosts täppa" on a cadastral map (laga skifte) 1834-39. Troed Rost was a soldier who lived here with his wife Nilla and several children. When he was discharged from the army in 1841, his eldest son Håkan probably took over this position. Maybe the smaller building was erected for the elderly couple at that time. Since the two sites were connected by a path, they should probably be seen in a common context.

However, while the written registers of different kinds give us the names, gender, and number of persons living at Rosts täppa, the archaeology has given us a firm picture of these people's everyday life and everyday environment, in a way that the written documents fail to do. Just by mapping the site, we can see how the inhabitants created their own micro-world. The multivocality when it comes to maintenance is evident. The arable fields together made up about 0.8 ha, which cannot have been sufficient to support the family. It is in this context that we must see the production sites for charcoal and tar as examples of how different types of resources were exploited to support the family.

From a spatial point of view, the archaeology shows that the crofters' lodging can be divided into different zones, connected to different types of use. It is also possible to see how the inhabitants could have structured space by demarcating different zones with stone walls and natural topography (Knarrström 2008b:87-90). The area around the house and courtyard was of course used for housing activities; the little field just north of the house was suitable for a kitchen garden. Cultivation took place east of the courtyard in a field clearly divided into three minor strips of land, which can be seen as evidence of some sort of agricultural division. North of this field a stony field seems to have been used for extensive farming activities. To the west of the house and courtyard, production of charcoal had taken place. Perhaps tar production also took place, although some of these remains were of medieval date. The area north of the house was used for storage and other types of activities. The wetland to the south was used for harvesting grass. 


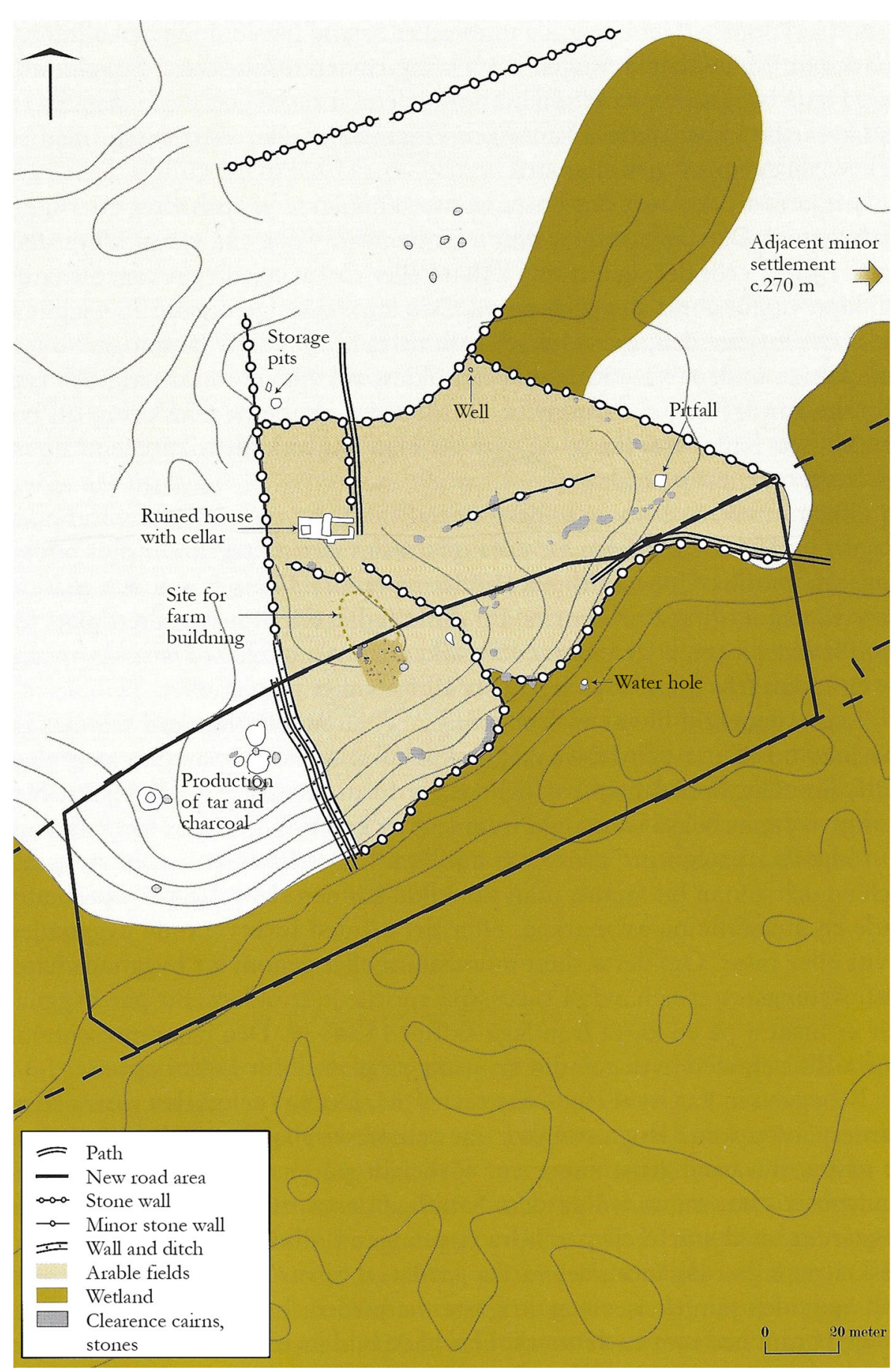

Fig. 2 The croft at "Rost's täppa," northern Scania. (After Knarrström 2008b: 81) 


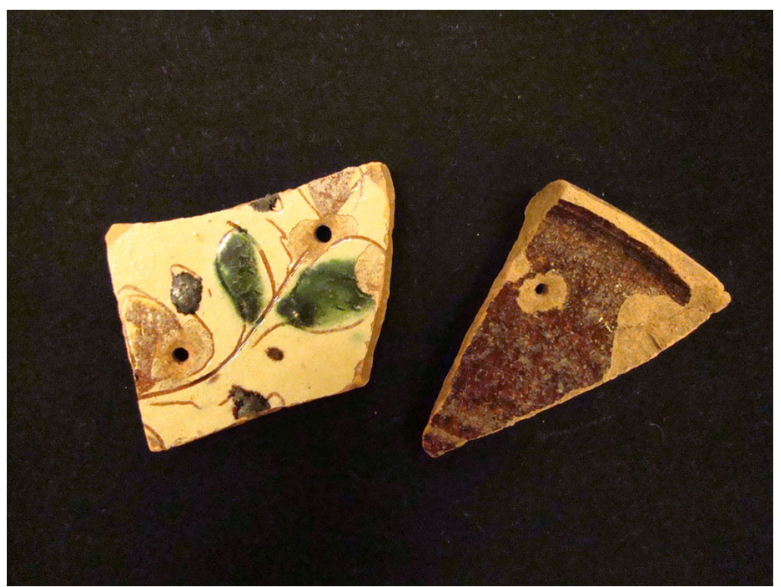

Fig. 3 Drilled holes in red earthenware from the smaller site at Rosts täppa, evidence of attempts at mending. (Photo A. Knarrström)

In this way it is possible hypothetically to reconstruct the everyday spatial experience of the people of the croft. Activities took place in specific zones, showing a well-structured everyday life. The well-made stone walls and other demarcating structures show the organizational and spatial skills of the people on the croft. Many efforts were made to create a neat and organized micro-world, which can be seen as an example of how important the homestead was for the poor (cf. Green 2011:95). An organized home created a piece of culture in the forested landscapes of northern Scania, as a reflection of their mindscape. At the same time the site is not only well-organized, it is also characterized by a kind of seclusion, with the back of the building turned toward the main road (Knarrström 2008b:95). It is thus possible to see how the crofters adjusted the matterscape, the physical landscape at the site, when they created their micro-cosmos with houses, fields, and land divisions. This was done according to prevailing rules and regulations, the existing powerscape, since the crofters were subordinate to the ordinary farmers and could not act in the landscape without permission. Still, they managed to create a milieu that shows how they perceived and understood their micro-cosmos.

\section{Subalterns in Urban Areas}

Simultaneously with the increase in the number of subalterns in the countryside, a similar growth took place in the Swedish towns, connected to the nineteenth-century industrialization, where manufacturers and new industries offered work. The group of industrial workers was heterogeneous, ranging from highly trained and skilled, for example, master smiths, to the large group of unskilled workers, more or less immediately replaceable. What they had in common was that they often did not own their dwellings, but were tenants. Thus, they can be seen as subalterns.

The industrialization and urbanization in Sweden boomed in the second half of the nineteenth century, when many cities expanded, both spatially and in the number of citizens. The Swedish population doubled from 1750 to 1850 , and then doubled once more from 1850 to 1950 . In $1850,90 \%$ of the population lived in the countryside; in 
1900 this share had decreased to $25 \%$. The impact of urbanization differed from town to town. In the major towns, the population grew considerably. In Stockholm, for example, the population increased from 84,000 in 1840 to close to 600,000 in 1940 . Towns like Borås, Västerås, Malmö, and Gothenburg saw an even larger growth in numbers, relatively speaking, while other towns grew at a much slower pace (Andrén 1943:83; Carlsson 1961:449-451; Gruvberger 1968). Living conditions in the towns were far from good and subalterns were exposed to many risks. Infant mortality was considerably higher in the towns than in the countryside, due to bad living conditions and poor hygiene. The larger the town, the higher the mortality (Gruvberger 1968:12).

Just as in the countryside, there were large differences within the group of urban subalterns, socially and economically, but they were all more or less completely active in a market economy, selling their skills for a wage that hopefully could support them. With the right skills, many workers could have good living conditions, as long as they stayed healthy and could manage their job. The absence of real property became a problem when people grew old. Without an income, it became impossible to pay rent.

Many of the people who moved to towns ended up living in slum quarters, often in bad conditions. This is a well-known history, brought to life by a number of novelists (cf. Fogelström 1960). The problem is how we as archaeologists can study these people. Specific working-class housing in the towns hardly existed before the middle of the nineteenth century. The exceptions were towns with major metal industries or other types of large manufacturers, where housing for the workers existed already in the seventeenth century. These houses were often uniformly built in large blocks. In the mining town of Falun, for example, there were houses for the miners, consisting of small plots with timbered houses with the gable at the street end, garden sheds, and garden land. At other industries, like the porcelain manufacturer Rörstrand, the workers lived in terraced houses (Andrén 1943:80, 83; Hellner 1943).

From the middle of the nineteenth century, apartment blocks built of timber, several stories high, were established for workers in many towns. They mainly consisted of one room and a kitchen and were intended for families. These lodgings were supplemented with hostels for single men. In Stockholm there were large areas with this type of houses in the outskirts of the town. Here the blocks were large and square, surrounded by a rectangular street grid, a result of strict town planning. The population increase led to a constant lack of housing, raised levels of rent and poor-quality housing. An 1865 committee in Gothenburg investigating the pauperism in the town noted the bad quality of the living conditions of the workers (Andrén 1943:83-85, 87; Paulsson 1950:551-553).

\section{The Archaeology of Subalterns in Urban Areas}

Finding examples of urban archaeological excavations focused on subalterns in Sweden is not an easy task. Compared to the international situation, this group is almost absent as both subject and object within Swedish urban archaeology (cf. Mayne and Murray 2001; Mayne 2011). There are some exceptions where archaeology has contributed to highlighting the lives of subalterns, but the excavations in question were originally focused on other problems. Here examples from Jönköping and Kalmar will be used. 
Jönköping is one of very few towns where post-medieval archaeology has been undertaken more or less continuously since the 1980s. In 2004 an area with building remains from the seventeenth to the nineteenth centuries were excavated. A large number of artisans' town plots were documented. Squeezed in between workshops and warehouses at the back of the plots, it was possible to document small rooms with heating that had been used for housing, probably as lodging for workers. At the beginning of the nineteenth century, a warehouse was converted into what is called in the written records from the town a "spisrum" ("room with heating"). Here a room with a simple tiled stove, a minimal vestibule with a small storage space together constituted a dwelling of about $20 \mathrm{~m}^{2}$. The living room was roughly $13 \mathrm{~m}^{2}$. The floor layer showed that the people living in the room had consumed a lot of fish, but not freshwater fish from the nearby lake Vättern as expected, but imported saltwater fish like herring, cod, and haddock from the North Sea to the west (Pettersson 2014:434-435, 440). This shows that subalterns in Jönköping were dependent on the market for food, probably since, not being landowners in the town, they did not have the right or possibility to fish for themselves in Vättern, the second largest lake in Sweden. Subalterns had to rely on cheap food available in the market, mainly salted herring (Fig. 4).

Subaltern lodgings were thus secondarily incorporated in an already established building structure. They can be seen as an example where the owners of town plots adjusted to new opportunities and needs in connection with the growing population of the town. Buildings previously used as warehouses and workshops were transformed into apartment blocks (Haltiner Nordström and Pettersson 2013:88, 94; Pettersson 2014:444). In Jönköping this development was revealed by the archaeology. The excavations in Jönköping also highlighted the problems with archaeological interpretations of building remains. In this case, when excavating nineteenth-century buildings, it became possible to compare what was found in the ground with other types of sources. The foundation of what looked like an ordinary house with two rooms of equal size on either side of a vestibule was dated to the beginning of the nineteenth century. One of the rooms was interpreted as a kitchen, the other as a living room. This building was also

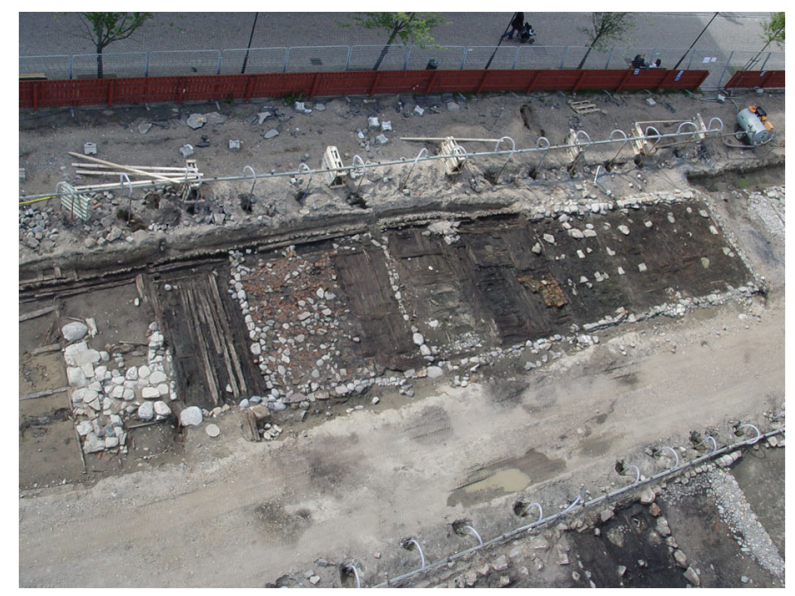

Fig. 4 A nineteenth-century combined warehouse and stable in kv. Apeln in Jönköping. In the middle of the building a small lodging with vestibule and a living room with a tiled stove. Photo Claes Pettersson, Jönköping läns museum. (After Pettersson 2014:439) 
visible on a photo from 1903. The photo shows that this was a building with three floors and an attic (Pettersson 2014:440-441). Instead of being an ordinary two-room house, this was a small apartment block with at least three apartments for subalterns.

The other example comes from the city of Kalmar. In connection with land development in the seventeenth-century urban area, building remains from the eighteenth and nineteenth centuries were also documented in twelve plots along Fiskargatan (Tagesson 2014). Houses that were demolished in the 1960s were excavated. In the written documents, workers, artisans, and groups of subalterns inhabited this part of town.

A comparison between written documents and archaeology shows that many plots were bought by persons not living on the site. The plots seem to have functioned as an investment. Some plots were partly uninhabited, others were leased to tenants in the eighteenth century. On many of the plots, small houses for whole households were found at the back of the plots. Other small buildings seem to have been homes for several tenant families. There is a tendency that houses seems to have been built directly for letting, as a strategy by the plot owner. Often widows seems to have been the instigators in this process, in connection with the new challenges that occurred when their living conditions changed when the husband died (Lindström and Tagesson 2016:207-208, 220-223). We find here the same conditions as in Jönköping, several small dwellings at the back of the plots, used by subalterns. A similar development has been noted in England (Nevell 2011). It also becomes very evident that richer and poorer families sometimes lived intermixed on the same plot in urban areas (Lindström and Tagesson 2016:210) (Fig. 5).

The examples from Kalmar and Jönköping show that subalterns can be found by archaeology also in urban areas. Integrated studies of both the written and the material record have great potential to show how subalterns were present over large parts of the town, not just in "slumlands." So far, true archaeological studies of nineteenth-century slumlands in Swedish towns are lacking. Archaeology done in the outskirts of towns has been focused on prehistoric or medieval remains. Very often slumland houses were demolished long ago without any documentation, disregarding the urban history of subalterns.

Looking at the subaltern archaeology done in Swedish towns, the connection to dwelling is evident. It is through "one-room-and-kitchen" and similar small living quarters that the subalterns have been identified. In both Kalmar and Jönköping the importance of close cooperation between historians and archaeologists can be seen, but also the importance of studying buildings via photos and drawings, as well as standing buildings (Lindström and Tagesson 2016; Pettersson 2014:440-441). The construction of standing buildings, their appearance and layout, simplifies the interpretation of archaeological remains below ground. This is a point that cannot be emphasized enough.

Urban subalterns were to a high degree tenants living on other people's plots and in apartment blocks. We must imagine these houses as being built in several stories. Traditional underground archaeology, as stated above, faces difficulties in how to correctly understand and interpret upper parts of buildings. A different approach is needed, where standing buildings are used as a starting point for buildingarchaeological studies, which can function as analogies (cf. Eriksdotter and Anglert 2018; Rimmer 2011). In order to study urban subalterns an approach that emphasizes building archaeology as method is needed. It is probably more fruitful to document buildings before they are demolished than to excavate them after they are gone. 


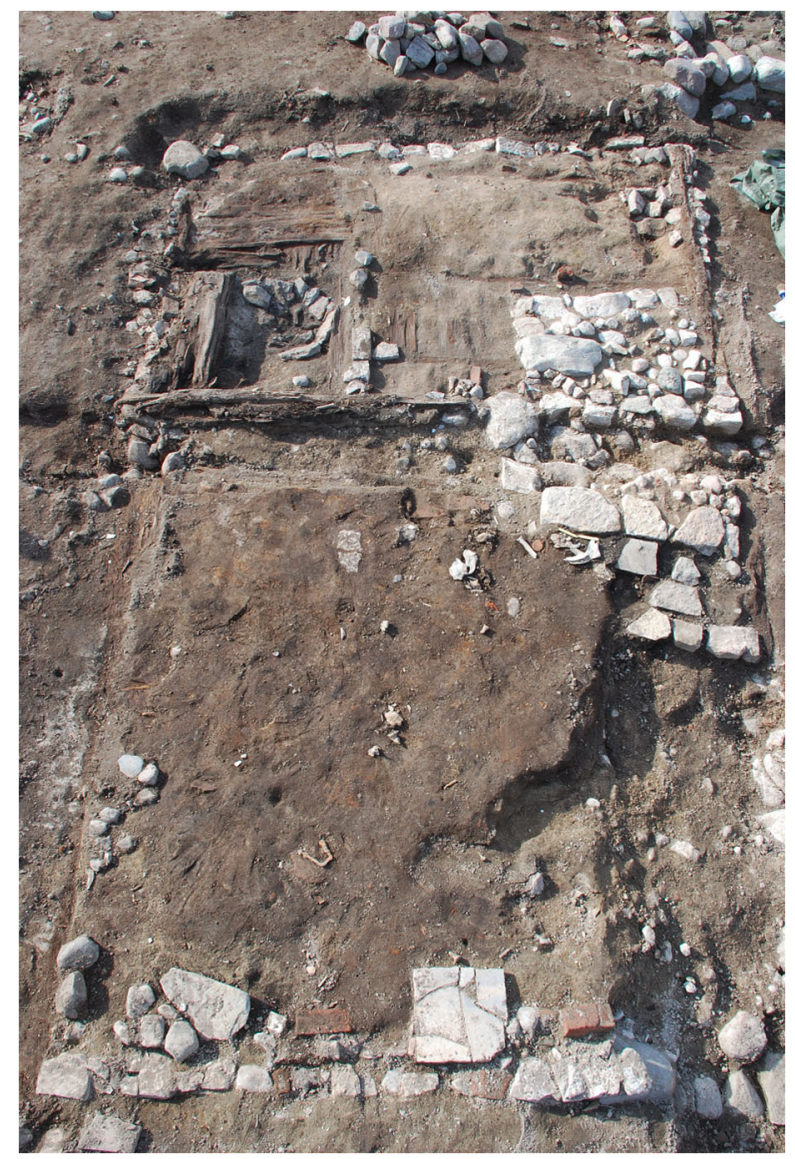

Fig. 5 A two-room house in the northern part of plot 288 in kv Gesällen, Kalmar. The house is dated to ca. $1730-40$ s. In the 1750 s the owners lived somewhere else and the house was let to the subaltern workman Anders Olsson and family, an example of how landowners invested in the housing market. (Photo G Tagesson, Arkeologerna, SHM)

The concepts of matterscape, powerscape, and mindscape are also applicable to urban subalterns. We can see how people organized their daily life in back yards and in rental housing, to different degrees being interrelated with other groups. In contrast to the countryside, space in urban areas was more regulated and fixed. Workers had to adjust to a strict spatial structure regarding where to live and where to work. The daily routine was standardized. This also functioned as a means to discipline the workforce (cf. Nassaney and Abel 2000:240-242). The matterscape was less available for individual initiative than in the countryside. Domination of the workforce was probably more pronounced and direct in urban areas, compared to the situation for rural crofters. The powerscape was everlastingly present and could be seen, for example, in the standardized apartment blocks. Detailed study of workers' cottages in towns can nevertheless reveal how the subaltern workers' homes, just as in the countryside, reflected their mindscape, even though this is not hitherto as clearly archaeologically detectable as in the countryside. This is probably due to the lack of archaeological studies of subalterns in urban areas. 


\section{Subalterns in Patriarchal Milieus}

The industrialization of the nineteenth century happened just as much in the countryside, where industries were established on sites with a good supply of either energy, usable goods, or workforce. Ironworks and sawmills are perhaps most typical. The introduction of steam power enabled localization on sites without waterpower. The countryside was also home to a large number of manorial estates controlling extensive areas of arable land, both as demesne and through tenant farms and crofts.

Ironworks and sawmills, just like manors, were patriarchal milieus, and functioned as something in between towns and countryside. The lord of the manor/ironworks/sawmill ruled over his household, tenants, and workforce alike. A patriarchal society, founded in a Lutheran spirit, sanctioned the subordination of households and workforces. This made manors and industries such as ironworks similar from a social point of view as regards social relations between different groups of people (Orser 1996:155-157; Stråth 2012:278280; Svensson et al. 2009). These were places where the workers either lived in barracks or in the surrounding countryside as crofters. Some of them had permanent positions, but a large number were seasonal laborers. While seasonal laborers had living quarters of very low standard, the permanent staff often got a dwelling as part of their employment. Often this was a one-room flat with kitchen in a barrack. Sometimes the workers also had access to a small piece of land for growing some crops, and they could also have the possibility to keep small animals for their own use. In the ironworks, the master smiths had the highest social and economic position within the workforce. The permanent, trained staff had a higher income and better living quarters than ordinary crofters, but they too were tied to their employers (Gruvberger 1968:124-127; Ford 2011).

An example where the relation between manor and crofters has been analyzed is Bergkvara in Småland in southern Sweden. Here studies have shown how material and spatial differences were clearly connected to social relations (Hansson 2005). The manor is beautifully situated by a lake, with a large garden and monumental agricultural buildings, many originating from the nineteenth century. The ruin of the medieval castle shows the history of the site. A large number of abandoned crofts in the presentday wooded landscape surround the manor. Historically the economy of the estate has been based on a combination of tenant farming and crofters, but from the nineteenth century onwards the number of crofters increased (Hansson and Nylén 2012; Larsson 1974).

In 1900 , most settlement connected to the estate can be characterized as crofts. From 32 in 1763, the number of crofts peaked in the middle of the nineteenth century at 130. The crofters were much more closely tied to the manor than the tenants, being forced to do much more day labor. In the middle of the nineteenth century a maximum of 130 days of day labor was demanded of some crofters annually, but the more normal number of days' labor was between 26 and 52. The subordinate crofts were much smaller than the tenant farms; the crofter had on average less than 0.8 ha of arable land, about one third of a standard tenant farm on the manor. The crofters also had less fertile land to farm (Larsson 1974:81-82).

From extant contracts signed between the lord and the crofter, it is possible to see that crofters not only worked on the manor, in the fields, and in the home on the croft. Many tasks had to be performed in the woodlands that surrounded the manor. The 
contracts were to some extent standardized, but also individual, stipulating whether the crofter had a specific task.

The manor also instigated some industries, especially connected to the nearby waterpower. In fact, the first mention of an estate in the area is connected to the mill by the manor, recorded for the first time in 1328. In the seventeenth century, the mill was expanded with a smithy and a sawmill, in 1789 by a mechanical workshop making iron nails and equipment for farming. A brewery was added to the industrial zone of the manor (Nordmark 2004). These industries also used a number of subalterns as a workforce, many of whom lived in nearby crofts.

From a spatial point of view, we can see that the crofts were located in a wide area surrounding the manorial center. Most crofts were located 1-5 km (as the crow flies) from the manor, which was quite a distance for some crofters when walking to do the day's labor. Maps from the nineteenth century also reveal differences between the largescale and well-cleared arable fields of the manor and the small-scale and stony fields of the crofts. While the fields of the manor were subject to drainage and clearing of stone to improve the harvest, this type of investments did not affect the fields of the crofts (Hansson 2005). The appearance of the arable fields themselves thus reveals social relations.

If archaeology were to be undertaken in any of the crofts surrounding Bergkvara, an understanding of the spatial and social context would be of the utmost importance. An example where this has been done is an excavation of a croft belonging to the manor of Mälby in Uppland, dating to the late eighteenth to early nineteenth centuries. Here the dwelling house was a small building constructed with unusually substantial stone walls of a type that is seldom found on crofts in the region, probably showing that it was the manor that had erected the dwellings, not the individual crofter. The manor had the resources, knowledge, and will to erect more permanent and imposing dwelling houses, which could function for several generations (Kjellberg 2008:31). If the wider social context in this case had not been incorporated in the interpretation process, this conclusion would never have been drawn.

\section{The Archaeology of Subalterns in a Patriarchal Milieu: The Example of Pinoberget}

A large number of crofts can be found in an area called Pinoberget, in the surroundings of the Älvsbacka ironworks in Värmland. Here a selection of the crofts have been subject to archaeological excavation, together with a larger mapping of the area. According to local tradition and historical documents, Pinoberget was a place where parts of the workforce of the ironworks had lived, even though the land in question belonged to different peasants in nearby hamlets. This was also home to the poorest in the community (Bodin et al. 2005, 2007; Lind et al. 2001; Svensson et al. 2009). Within an area of about $1250 \times 750 \mathrm{~m}$, remains of some 40 buildings of different kinds were documented. Many of the houses lay adjacent to small arable fields and other types of cleared spaces. Sites for the production of charcoal and tar were also found in the area. It is unclear, however, whether all of these remains were contemporary. The different houses, some lying adjacent to each other, were connected by a narrow path (Fig. 6). 


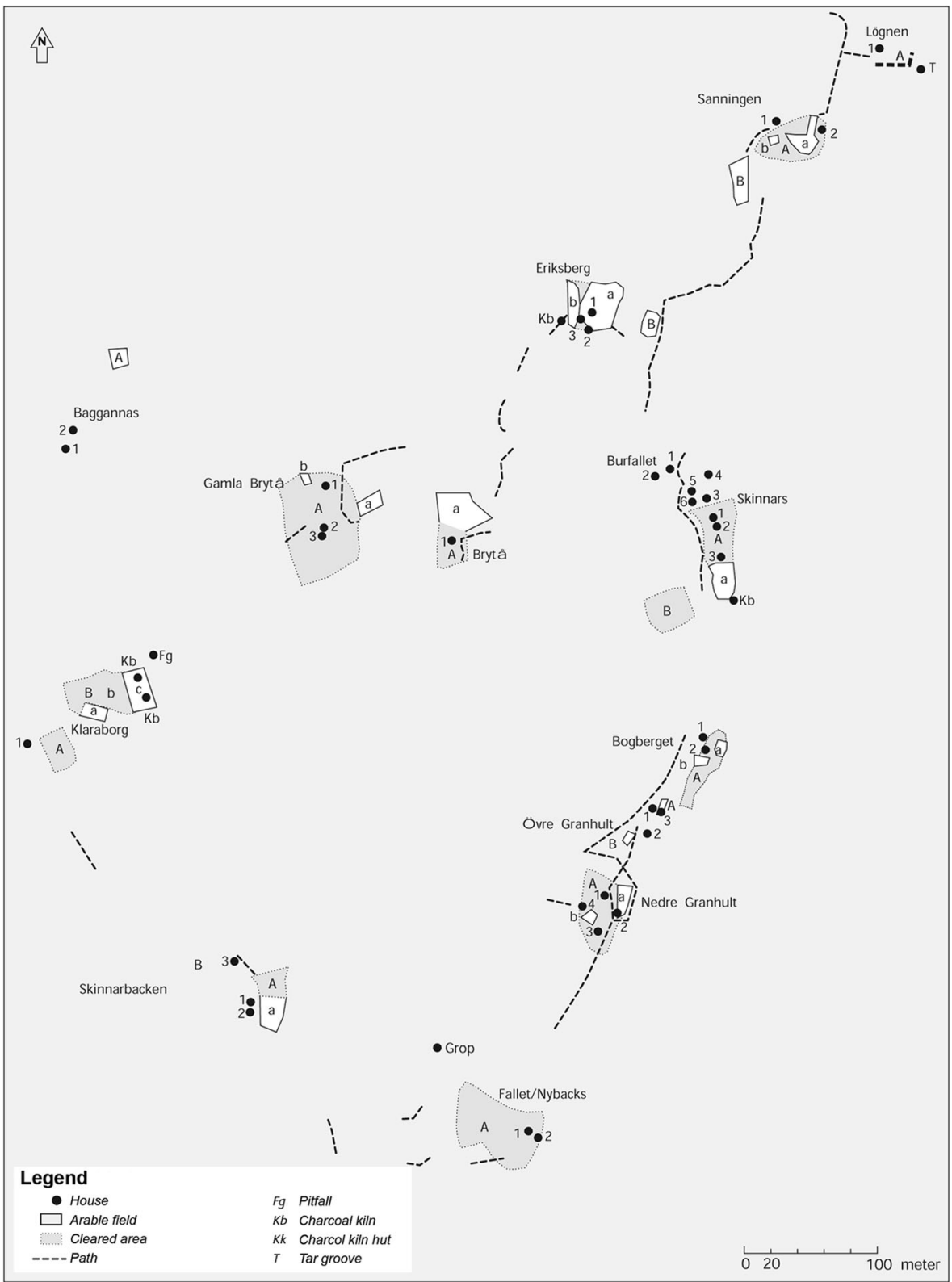

Fig. 6 Map showing the registered building remains at Pinoberget. The lodgings were clustered in groups along a pathway. (After Lind et al. 2001:65)

Fieldwork revealed that the houses, despite initially looking similar, were of different kinds. Their size and construction varied and some of the buildings had a dominant position in the landscape, on small hills, and on heights. While some houses had one or two rooms and stood on a stone sill, others were dug into a slope. Some houses must have been visible at a distance, while others had a more secluded location. Some of the larger houses were also connected to larger arable fields. Farming seems to have been 
more important for subsistence at some settlements than others. Here the inhabitants were probably connected more closely to work at the ironworks. The small artifacts retrieved from the three excavated sites were rather similar, despite the fact that these sites had a somewhat different house construction (Fig. 7).

The consumption patterns were the same regardless of the social and economic status of the individual site. It was noticeable, both in the written sources and in the archaeological finds, that many of the inhabitants were involved in some kind of handicraft. At one of the sites, Nedre Granhult, traces of shoemaking and parts of a sewing machine were found. These handicrafts were invisible in the written sources. It is very likely that different types of handicraft were important for the subsistence of the people of Pinoberget, especially after the ironworks had closed in the late nineteenth century. It was also evident that much of the material culture, the small finds, were goods purchased in the nearby shop at the ironworks. It was thus clear that these people were involved in a market for consumer products.

Something that also became evident in this project was the large problems of connecting the terminology found in the written sources, torp, backstuga, and so on, to the actual material remains at a specific site. At Pinoberget, the registers mention backstuga, which was a place for subalterns, who according to the rule, did not pursue farming on their own, but here several examples could be found showing that people actually did some sort of farming.

Archaeology was able to reveal that there were numerous differences between the sites in the area, which shows that they were homes for many families with different social living conditions. The inhabitants at Pinoberget were subordinated to the owner of the ironworks in Älvsbacka, which, like any other ironworks, was a strict hierarchical milieu. Social relations were based on discipline and distance and the hierarchy was clearly visible in the landscape, with the manor of the ironworks as the focal point. Just as in urban areas, the matterscape at the ironworks was controlled and there was a lack of possibilities for the workers to express themselves. Housing was often provided by the ironworks. The workers bought the supplies and products they needed in the ironworks shop (Svensson et al. 2009:186-187). The control was evident and visible

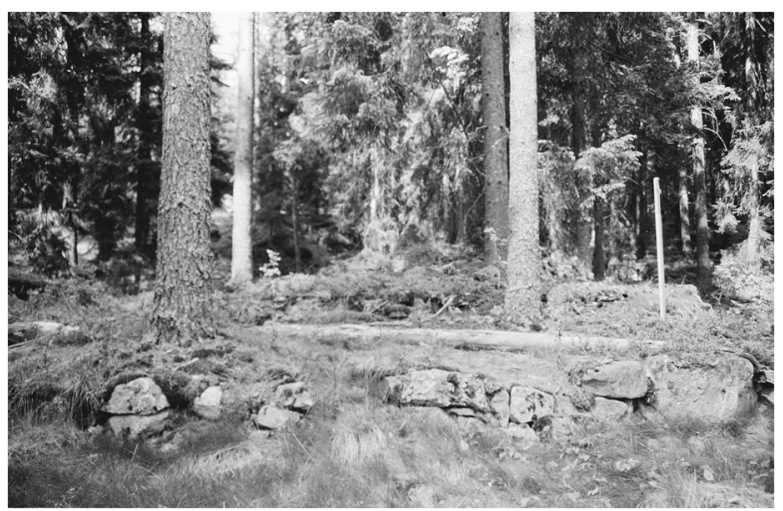

Fig. 7 The remains of the croft at Nedre Granhult, Pinoberget. A terrace and the foundation of the fireplace are visible. (Photo Eva Svensson) 
both at the workspace and in domestic spaces with standardized housing (cf. Nassaney and Abel 2000:260-264).

For the parts of the workforce that lived at places like Pinoberget, possibilities to create a home according to individual preferences were much greater. The powerscape of the ironworks diminished and was replaced by the powerscape of the landowning peasants. They were not always present, however, which gave the subalterns greater opportunities to express their own individuality. Their individual living conditions - in a way their mindscapes - were revealed by the archaeology. In the written material, Pinoberget gives the impression of being inhabited by a common group of subaltern people, in more or less similar conditions. The archaeology was able to show that this was not the case; this group of people could be further divided and individual living conditions emerged. They appear just like the complex group of people that Gramsci described. The subalterns at Pinoberget all used the same physical environment, the same matterscape, according to the rules and regulations of the local powerscape, which was a mix of the powerscape of the ironworks and the peasants. The variation in the archaeological record shows that they created individual homesteads, reflections of different mindscapes. The differentiation can in itself be seen as a contrast to the strictly regulated space at the ironworks. The archaeology has clearly increased the complexity of the narrative of the area of Pinoberget.

\section{Conclusion}

As the examples above have shown, there are many reasons why we should do archaeology with this type of material remains. In many cases, archaeology contributes to new and specific knowledge that otherwise is disregarded. The material culture should be the main starting point for us as archaeologists when looking for a different history, used in triangulation with written documents, maps, images, and folklore. Archaeological excavations of late remains clearly possess the power to produce new and independent knowledge. What often has become evident is that archaeological studies of subaltern milieus, especially in the countryside, in several cases have shown a much more multivocal history from the one presented in written documents. The master narratives can be challenged.

A vital contribution of archaeology is spatiality, which traditional studies focused solely on written documents can seldom give. Through archaeology we can document and analyze the space and landscape of the subalterns in much more detail. The material remains, houses, fields, and roads show the space of the subalterns in detail, how they organized their space for everyday life. It becomes possible to analyze changes of subsistence and land use in different contexts, spatially and chronologically. This can be seen as being connected to how the subalterns adjusted to the physical reality, the matterscape. This physical reality was used according to the possibilities the subalterns were given by the norms, objectives, regulations, and power structures, the powerscape of society. This powerscape could differ within the group of subalterns, thus resulting in different types of understanding of everyday life as the examples of Rosts täppa and Pinoberget show. In urban and industrial milieus, the stricter spatial control helped to discipline the workforce. The subalterns thus created their own individual mindscape according to how they could respond to the conditions of the 
powerscape. This was done in a continuous dialectic. In this way archaeology can help to individualize the otherwise invisible and largely ignored group in society. Archaeology can make the subalterns speak (cf. Orser 1996:159-182; Spivak 1988).

It is evident that much remains to be done on the topic of the archaeology of the subalterns in Sweden, but some tentative conclusions can be drawn. It is interesting to note how the subalterns in the countryside often lived isolated in remote locations, far away from villages, manors, and industries. Paupers were clustered in certain areas (cf. Svensson, Hansson and Nilsson in prep.). Subalterns were deliberately made invisible. The lord of the manor, or the owner of the ironworks, did not have to see the places where his subordinate workforce lived. In urban areas, by contrast, it seems as if the subalterns until the mid-nineteenth century lived much more intermingled with other groups of people, as their small lodgings could be found in the back yards of the town plots. It is not until the mid and late nineteenth century that "slumlands" started to emerge in some towns. Perhaps we can here discern different attitudes toward subalterns in towns compared to the countryside. Perhaps the separation of rich and poor in society became more profound in the nineteenth century. When the number of poor people grew, it became more important to separate this group from the rest of society. Was this when a derogatory attitude toward poor people became widespread? We can nevertheless conclude that much needs to be done on the topic of subalterns, in order to make them more visible and a mainstream topic of historical research. Archaeology has a great deal to contribute to this process.

Acknowledgements The study was financed by the Swedish National Heritage Board. The English was revised by Alan Crozier.

Open Access This article is distributed under the terms of the Creative Commons Attribution 4.0 International License (http://creativecommons.org/licenses/by/4.0/), which permits unrestricted use, distribution, and reproduction in any medium, provided you give appropriate credit to the original author(s) and the source, provide a link to the Creative Commons license, and indicate if changes were made.

Publisher's Note Springer Nature remains neutral with regard to jurisdictional claims in published maps and institutional affiliations.

\section{References}

Andrén, E. (1943). Städernas arbetare. In Lindblom, A., ed., Den svenska arbetarklassens historia: Arbetaren $i$ helg och söcken. Kulturhistoriska studier. Hus och hem. Band 4, del 1. Tiden, Stockholm, pp. 79-92.

Andrén, A. (1998). Between Artifacts and Texts: Historical Archaeology in Global Perspective. Plenum Press, New York.

Apel, J. and Welinder, S. (2007). Ett torp och ett artefaktmönster. In Welinder, S., ed., Torpens arkeologi. Riksantikvarieämbetets Arkeologiska Undersökningar, Stockholm, pp. 139-154.

Bäck, K. (1992). Början till slutet: Laga skiftet och torpbebyggelsen i Östergötland 1827-65. Noteria, Borensberg.

Bellini, C., Bianchi, E., Boothman, D., D’Alessandro, M., Ferraresi, A., Foschi, M. L., Guerreri, M., Locatelli, M., Magaguti, L., Palmieri, F., Romolo, A., and Tassinari, C. (2010). The history of the subaltern groups: Rome and the middle ages in Italy. International Gramsci Journal 2: 14-20.

Bodin, S., Hulling, H., Pettersson, S., and Svensson, E. (2005). Olika perspektiv på föremål: materiell kultur hos obesuttna ca 1900. META 1: 3-20. 
Bodin, S., Hulling, H., Pettersson, S., and Svensson, E. (2007). Familjen Granquist på Pinoberget - materiell kultur i en backstuga. In Welinder, S., ed., Torpens arkeologi. Riksantikvarieämbetets Arkeologiska Undersökningar, Stockholm, pp. 173-200.

Carlsson, S. (1961). Svensk Historia II. Tiden efter 1718. Bonniers, Stockholm.

Castree, N., Kitchin, R., and Rogers, A. (2013). Subaltern Studies. A Dictionary of Human Geography. http:/www.oxfordreference.com.ludwig.lub.lu.se/view/10.1093/acref/9780199599868.001.0001/acref9780199599868-e-1811, (accessed January 30, 2019).

Chakrabarty, D. (2000). Subaltern studies and postcolonial historiography. Nepantia: Views from South 1:1: 932. https://muse.jhu.edu/, (accessed January 30, 2019).

Dodgshon, R. A. (1987). The European Past: Social Evolution and Spatial Order. Macmillan, Basingstoke.

Dodgshon, R. A. (1998). Society in Time and Space: A Geographical Perspective on Change. Cambridge University Press, Cambridge.

Elgeskog, V. (1945). Svensk torpbebyggelse från 1500-talet till laga skiftet. En agrarhistorisk studie. LT Förlag, Lund.

Eriksdotter, G. and Anglert, M. (2018). Människor byggnader sammanhang: Idéskrift om en utvecklad byggnadsarkeologi. Riksantikvarieämbetet, Stockholm.

Fogelström, P. A. (1960). Mina drömmars stad. Bonnier, Stockholm.

Ford, B. (2011). Worker housing in the Vermont copper belt: improving. International Journal of Historical Archaeology 15: 725-750.

Gadd, C.-J. (2000). Det svenska jordbrukets historia: Den agrara revolutionen 1700-1870. Natur and Kultur, Stockholm.

Green, A. (2011). Heartless and unhomely? dwellings of the poor in East Anglia and North-East England. In McEwan, J. and Sharpe, P., eds., Accomodating Poverty: The Housing and Living Arrangements of the English Poor, c. 1600-1850. Palgrave Macmillan, Basingstoke, pp. 69-101.

Gruvberger, N. (1968). Det industriella genombrottet. In Carlsson. S. and Rosén, J., eds., Den svenska historien 9. Industri och folkrörelser 1866-1920. Bonniers, Stockholm, pp. 118-130.

Haltiner Nordström, S. and Pettersson, C. (2013). Vapensmedernas gårdar: Arkeologiska undersökningar vid Smedjegatan. Faktorismide, köpenskap och bebyggelse 1620-1950. Arkeologisk rapport 2013:48. Jönköpings läns museum, Jönköping.

Hansson, M. (2005). Gods, människor och landskap: Bergkvara under 700 år. Rapport 2005:23, Smålands museum, Växjö.

Hansson, M. and Nylén, A. (2012). Bergkvara - ett godslandskap med historia. Kulturmiljö av riksintresse. Länsstyrelsen i Kronobergs län, Växjö.

Hellner, B. (1943). Brukens arbetare. In Lindblom, A., ed., Den svenska arbetarklassens historia: Arbetaren $i$ helg och söcken. Kulturhistoriska studier. Hus och hem. Band 4, del 1, pp. 93-114.

Høst-Madsen, L. (2016). Nyere historisk arkæologi i fortiden og fremtiden. Gefion 1 - arkæologi og nyere tid, $103-129$.

Jacobs, M. (2006). The Production of Mindscapes: A Comprehensive Theory of Landscape Experience. Doctoral dissertation, Wageningen University, Wageningen.

Kjellberg, J. (2008). En stenstuga vid Mälby säteri: Bebyggelselämningar från historisk tid i Tillinge socken. Rapport 2008:11. Upplandsmuseet, Uppsala.

Knarrström, A. (2008a). Grisavad: Ett torp åt skogen. In Anglert, M. and Lagerås, P., eds., Människorna och skogen: Arkeologiska platser i Örkelljungatrakten. Riksantikvarieämbetet, Stockholm, pp. 55-78.

Knarrström, A. (2008b). Torpet Rosts täppa: Det lilla i det stora. In Anglert, M. and Lagerås, P., eds., Människorna och skogen: Arkeologiska platser i Örkelljungatrakten. Riksantikvarieämbetet, Stockholm, pp. 79-100.

Knarrström, A. (2009). Grisavad, Rosts täppa och Carl Jonassons: Arkeologi på torp i Skåne och Blekinge. Ale, Historisk tidskrift för Skåne, Halland och Blekinge 2009(1): 24-36.

Larsmo, O. (2017). Swede Hollow. Bonnier Pocket, Stockholm.

Larsson, L.-O. (1974). Utsikt mot ett gods: Bergkvara under sju sekler. In Almqvist, S., ed., Bergunda. Öja Hembygds- och Kulturminnesförening, Växjö, pp. 57-129.

Lefebvre, H. (1991). The Production of Space. Basil Blackwell, Oxford.

Lind, H., Holmgren, I., Svensson, E., and Emilsson, S. (2001). Pinoberget: En socialhistorisk studie utifrån sentida bebyggelselämningar och obesuttna människor. In Lind, H., Svensson, E., Hansson, J., eds., Projekt uppdragsarkeologi: Sentida bebyggelse $i$ antikvarisk och arkeologisk verksamhet, Kunskapsavdelningen Rapport 2001:2. Riksantikvarieämbetet, Stockholm, pp. 47-88.

Lindström, D. and Tagesson, G. (2016). Ägande, boende och hushåll på Kvarnholmen under 1700-talet. In Carelli, P. and Tagesson, G., eds., Kalmar mellan dröm och verklighet: Konstruktionen av den tidigmoderna staden. Arkeologerna. Statens Historiska Museum, Stockholm, pp. 202-223. 
Little, B. J. (2007). Historical Archaeology: Why the Past Matters. Left Coast Press, Walnut Creek, CA.

Mayne, A. (2011). Beyond metrics: reappraising York's Hungate "slum." International Journal of Historical Archaeology 15: 553-562.

Mayne, A. and Murray, T., eds. (2001). The Archaeology of Urban Landscapes: Exploration in Slumlands. Cambridge University Press, Cambridge.

McGuire, R. (2006). Marxism and capitalism in historical archaeology. In Hicks, D. and Beaudry, M. C., eds., The Cambridge Companion to Historical Archaeology. Cambridge University Press, Cambridge, pp. $123-142$.

Mooreland, J. (2001). Archaeology and Text. Duckworth, London.

Mrozowski, S. A. (2000). The growth of Managerial Capitalism and the Subtleties of Class Analysis in Historical Archaeoloy. In Delle, J. A., Mrozowski, S. A., and Paynter, R., eds., Lines That Divide. Historical Archaeologies of Race, Class, and Gender. University of Tennessee Press, Knoxville, pp. 276305.

Nassaney, M. S. and Abel, M. R. (2000). Urban spaces, labor organization and social control: lessons from New England's nineteenth-century cutlery industry. In Delle, J. A., Mrozowski, S. A., and Paynter, R., eds., Lines That Divide. Historical Archaeologies of Race, Class, and Gender. University of Tennessee Press, Knoxville, pp. 239-275.

Nevell, M. (2011). Living in the Industrial City: housing quality, land ownership and the archaeological evidence from industrial Manchester, 1740-1850. International Journal of Historical Archaeology 15: 594-606.

Nilsson, P. (2010). Bortom åker och äng - förekomst och betydelse av kvarnar, fiske, humle- och fruktodlingar enligt de äldre geometriska kartorna (ca 1630-1650). Sveriges lantbruksuniversitet, Ultuna.

Nordmark, H. (2004). Vatten, jord och skog: Historia om industrin och dess förutsättningar i Bergunda socken. In Årenäs, S.-E., Posse, K., and Nässert, M., eds., Bergunda - en återblick del II. Bergunda Hembygdsförening, Växjö, pp. 25-41.

Orser, C. E., Jr. (1996). A Historical Archaeology of the Modern World. Plenum, New York.

Orser, C. E., Jr. and Fagan, B. M. (1995). Historical Archaeology. HarperCollins, New York.

Paulsson, G. (1950). Svensk stad: Liv och stil i svenska städer under 1800-talet. Del I:2. Bonniers, Stockholm.

Pettersson, C. (2014). De osynligas rum. In Nordman, A.-M., Nordström, M., and Pettersson, C., eds., Stormaktsstaden Jönköping: 1614 och framåt. Jönköpings läns museum, Jönköping, pp. 433-445.

Rathje, W. and Mullen, C. (1992). Rubbish! The Archaeology of Garbage. HarperCollins, New York.

Rimmer, J. (2011). People and their buildings in the working-class neighborhood of Hungate, York. International Journal of Historical Archaeology 15: 617-628.

Rosén, C. (1999). Fattigdomens arkeologi - reflexioner kring torpens och backstugornas arkeologi. In Artelius, T., Englund, E., and Ersgård, L., eds., Kring västsvenska hus - boendets organisation och symbolik $i$ förhistorisk och historisk tid. Institutionen för arkeologi, Göteborgs universitet, Göteborg, pp. 99-107.

Rosén, C. (2001). Arkeologi i arkiven - bouppteckningar och jordfynd i en halländsk by ca 1750-1850. In Andrén, A., Ersgård, L., and Wienberg, J., eds., Från land till stad: En medeltidsarkeologisk resa tillägnad Hans Andersson. Lund Studies in Medieval Archaeology 29. Stockholm, pp. 105-112.

Rosén, C. (2007). Torpare och materiell kultur. In Welinder, S., ed., Torpens arkeologi. Riksantikvarieämbetets Arkeologiska Undersökningar, Stockholm, pp. 61-78.

Spivak, G. C. (1988). Can the subaltern speak? In Nelson, C. and Grossberg, L., eds., Marxism and the Interpretation of Culture. MacMillan, London, pp. 24-28.

Stråth, B. (2012). Sveriges Historia 1830-1920. Norstedts, Stockholm.

Svensson, E. (2001). Bebyggelselämningar från modern tid - massmaterial eller individuella historier? In Andrén, A., Ersgård, L., and Wienberg, J., eds., Från stad till land. En medeltidsarkeologisk resa tillägnad Hans Andersson. Almqvist \& Wiksell International, Stockholm, pp. 353-360.

Svensson, E., Bodin, S., Hulling, H., and Pettersson, S. (2009). The crofter and the iron works: the material culture of structural crisis, identity and making a living on the edge. International Journal of Historical Archaeology 13: 183-205.

Svensson, E., Amundsen, H. R., Holm, I., Hulling, H., Johansson, A., Löfgren, J., Nilsson, P., Nilsson, S., Pettersson, S., and Stensby, V. (2018). Empowering marginal lifescapes: the heritage of crofters in between the past and the present. International Journal of Heritage Studies 24(1): 17-34.

Tagesson, G., ed. (2014). Kvarteret Gesällen 4 och 25. Särskild arkeologisk undersökning, Kalmars stad och kommun, Kalmar län, Arkeologiska uppdragsverksamheten, Rapport 2014:93. Riksantikvarieämbetet, Stockholm.

Welinder, S. (1992a). Människor och artefaktmönster. Societas archaeologica Upsaliensis, Uppsala.

Welinder, S. (1992b). Människor och landskap. Societas archaeologica Upsaliensis, Uppsala. 